\title{
Analysis of the features and causes of the contamination in the Shandi River basin
}

\author{
Hong Shi ${ }^{1}$, Yongbo Zhang ${ }^{2 *}$, and $L i$ Tang ${ }^{2}$ \\ ${ }^{1}$ Taiyuan University of Technology College of Environmental Science \& Engineering, Taiyuan030024,China \\ ${ }^{2}$.Taiyuan University of Technology College of Water Science \& Engineering, Taiyuan 030024,China
}

\begin{abstract}
This study examined the contamination of the surface water in the Shandi River basin in Yangquan, Shanxi province. A total of 11 sampling points (numbered S1-S2, S3-S4, S5-S11) were selected from the upstream to the downstream of the river, and 19 indexes were selected for inspection to identify the causes and features of contaminated water in the basin. The Nemerow Pollution Index was applied to evaluate the quality of the surface water and the overall extent of contamination in the basin. The result revealed that the content of $\mathrm{Cl}^{-}, \mathrm{As}, \mathrm{Cr}^{6+}, \mathrm{CN}^{-}$, and volatile phenols met the grade III water quality standards in China, and the remaining indexes exceeded the standards by varying degrees. The five sources of contamination in the basin negatively affect the environment. The presence of contaminants at the sampling points was in the following order, from highest to lowest: $\mathrm{SO}_{4}{ }^{2-}=\mathrm{Mn}=\mathrm{NH}_{3}-\mathrm{N}>\mathrm{Fe}^{2+}=\mathrm{Hg}>\mathrm{Fe}^{3+}>$ $\mathrm{Cd}>\mathrm{Zn}=\mathrm{F}^{-}>\mathrm{COD}>\mathrm{NO}_{3}{ }^{-}=\mathrm{NO}_{2}{ }^{-}$. The severity of the comprehensive contamination indexes decreased in the order of $\mathrm{S} 6>\mathrm{S} 9>\mathrm{S} 7>\mathrm{S} 11>\mathrm{S} 10>\mathrm{S} 3>\mathrm{S} 8>\mathrm{S} 5>\mathrm{S} 4$.
\end{abstract}

\section{Introduction}

Shanxi province has abundant coal resources; however, in recent years, coal mines have been consolidated and many of them been closed down because the coal resources were exhausted after continuous mining. In Yangquan, Shanxi province, a number of goaves were abandoned because of excessive mining. After mines are closed for a period of time, mine water accumulates in the mines and pockets of water develop that become trapped in the goaves ${ }^{[1]}$, yielding acid mine drainage. As drainage continues to gather, the water level may rise and eventually overflow a mine to the surface, resulting in severe environmental damage, negative effects on people's lives, and a high level of social and governmental concern. The Shandi River basin is a highly typical instance of this process.

The contaminated acid mine drainage within the Shandi River basin is mostly concentrated in the carbonate rock leakage sections near the Niangzi Pass spring field and greatly affects the karst underground water within the region. Liang's ${ }^{[2]}$ research stated that the springs at Niangzi Pass have been seriously contaminated because of the leakage of the acid mine drainage in parts of the region, specifically the Taohe River, Wenhe river, and Nanchuan River leakage sections, which contaminate the karst underground water. Huo's ${ }^{[3]}$ study indicated that the main routes of contamination in the Niangzi Pass spring field are the following two: Pollutants and atmospheric precipitation enter the river course and

*Corresponding author:ty_zyb@sina.com 
directly infiltrate the ground surface where carbonate rocks are exposed to supply the karst underground water; and precipitation indirectly seeps into the coverage zone of carbonate rocks and supplies the karst underground water.Mining is the most influential factor on the groundwater environment in the Niangzi Pass spring field. Wang [4] conducted an analysis and suggested that pyrite within coal seams and the surrounding strata oxidizes and hydrolyzes during coal mining. Therefore, this study focused on the surface water condition of the Shandi River and selected sampling points within the Shandi River basin on the basis of the geologic environment, mining activities, and the current condition of abandoned mines. The level, volume, and quality of the river water were monitored, and water samples were collected and analyzed to examine the actual sources and distribution of contamination along with the levels and features of the contaminants. In this study, the harm of contamination on Niangzi Pass was specified, and corresponding management measures are suggested.

\section{The general situation of the studied region}

The Shandi River basin is $58 \mathrm{~km}^{2}$ in area, and the overall geology in this region is complex. The lithology of the stratum is relatively complete, with loess covering most of the area and bedrock partially exposed. The geological structure and the hydrogeological condition are simple. Ordovician carbonate karst aquifer is the main composition of the four types of groundwater aquifer groups that are found in the region. The aquiclude is mainly a combination of Carboniferous mudstone and sandstone, and mudstone predominates in the Upper Carboniferous Taiyuan Formation and Permian Shanxi Formation. The main source that contributes water to the aquifer is precipitation, and the water is primarily discharged from wells, springs, natural evaporation, and human activities. In 2009, the mines in the region were integrated and reorganized, and currently, only eight mines remain, with one of them being an open-pit mine.

After field studies and investigations were conducted, five sources of contamination were found to cause the contamination in the basin:

Contamination source I: Yankan coal washery. The coal washery discharges a massive amount of coal washing wastewater into the river course. Coal ash floats on the river surface, causing the river water to be black and turbid; the $\mathrm{pH}$ value at this sampling point has changed, showing that the river has been contaminated.

Contamination source II: Dishui Cliff comprehensive contamination source. The Yuejin mining site lies on the southwest of Dishui Cliff. The mining site is equipped with a sewage treatment plant with a treatment capacity of 10.000 $\mathrm{m}^{3} / \mathrm{d}$. The mine water is managed before discharge; however, acid mine drainage is nevertheless observed in the mines and it flows into the Shandi River through its river course. The $\mathrm{pH}$ value of the sampling point was measured at 4.0 , which indicates that the river has been contaminated by acid mine drainage.

Contamination source III: Xiaogou village open-pit mine contamination source. Mine water gathers in multiple mine shafts in the open-pit mine, and the sources of the gathered water are precipitation and groundwater. The gathered water is yellowish-brown and relatively turbid, and the water quality is extremely poor, with a $\mathrm{pH}$ value around 2.5 . The gathered water infiltrates into the ground ${ }^{[5]}$ directly and participates in groundwater circulation.

Contamination source IV: Shandi village Miaogou Stream contamination source. The Miaogou Stream carries surface runoff from $9 \#$ and 12\# acid mine drainage. The acid mine drainage streams constantly from the outflow site and results in a flow that is reddish-brown.The tested water had a $\mathrm{pH}$ value of approximately 2 and was turbid with an acidic smell. When precipitation is heavy, the water volume in the ditch increases, gathers into a surface runoff, and flows into the Shandi River; accordingly, the acid mine drainage seriously contaminates the river ${ }^{[6]}$.

Contamination source V: Shandi village Menlou Liu Stream. The source of the acid mine drainage at this site is uncertain, but the stream is supplied during high-flow season; therefore, the amount of leakage is higher in high-flow seasons than in low-flow seasons. The Liu Stream receives acid mine drainage from an evident outflow point near Menlou, Shandi village, and the outflow point supplies a large amount of acid mine drainage in a high-flow season and a very little in a low-flow season. A highway and a bridge are built above the stream. The stream goes through cultivated fields, flows to lower ground, and enters the river course; hence, the acid mine drainage causes serious contamination of the river. 
The location of Shandi River and the distribution of mining sites and contamination sources are displayed as Figure 1.

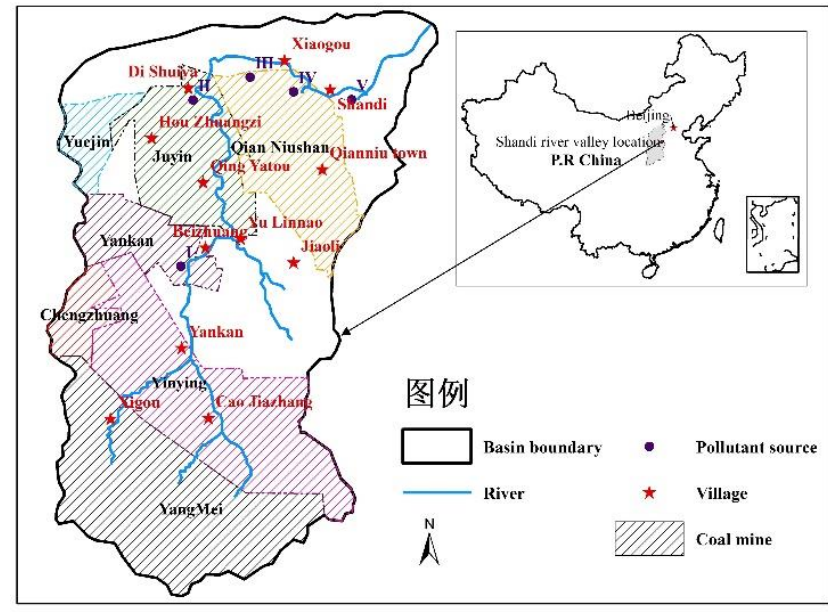

Figure 1. Location of Shandi River and the distribution of mining sites and contamination sources

\section{Research method}

\subsection{Placement of sampling points}

According to the hydrogeological condition of the Shandi River basin and the principle of having an even and feasible arrangement of sampling points, 11 sampling points were placed from south to north along the river. The distribution of the sampling points is depicted in Figure 2. The upstream lies to the south of Yankan, the midstream extends from Yankan to Zhainao village, and the downstream is located to the south of Zhainao village. The upstream, midstream, and downstream areas received 2, 2, and 7 sampling points, respectively, with sampling points numbered S1-S2, S3-S4, and S5-S11 in order from upstream to downstream.

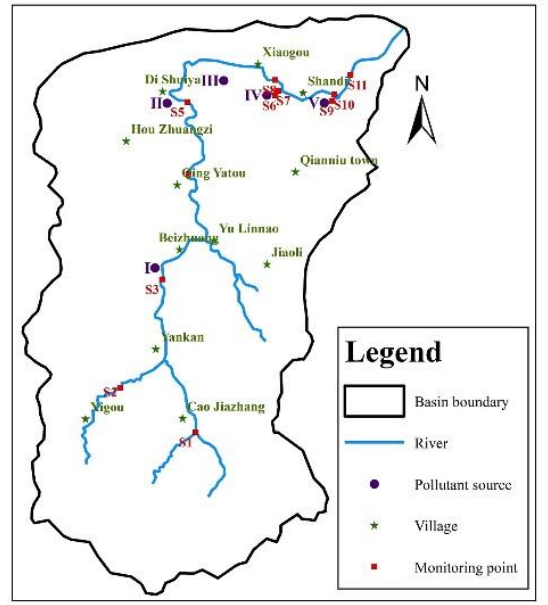

Figure 2. Distribution of the monitored sampling points in the basin

\subsection{Selection of the analysis indexes of the water} samples

The selection of the indexes for monitoring the surface water was based on the environmental quality standards for surface water and the environmental quality standard for soils in China. The main items of inspection can be categorized into two types: (1) general comprehensive indexes that reflect water quality, such as temperature, chromaticity, $\mathrm{pH}$ value, and electric conductivity; and (2) indexes that signify toxic substances, including the content of $\mathrm{Pb}, \mathrm{Cr}, \mathrm{Cd}, \mathrm{Hg}$, and organic pesticides. According to the actual situation in the Shandi River basin, this study selected a total of 19 indexes with which to assess the water samples: seven cations and anions (i.e., $\mathrm{Fe}^{3+}, \mathrm{Fe}^{2+}, \mathrm{SO}_{4}{ }^{2-}, \mathrm{NO}_{3}^{-}, \mathrm{NO}_{2}^{-}, \mathrm{Cl}^{-}$, and $\mathrm{F}^{-}$), seven heavy metal pollutants (i.e., $\mathrm{Zn}, \mathrm{As}, \mathrm{Hg}, \mathrm{Cd}, \mathrm{C}_{\mathrm{r}}{ }^{6+}, \mathrm{Pb}$, and $\mathrm{Mn}$ ), and five additional indexes; $\mathrm{CN}^{-}, \mathrm{H}_{2} \mathrm{~S}, \mathrm{NH}_{3}-\mathrm{N}$, which cause severe water pollution, oxygen consumption demand (COD), and volatile phenols.

\subsection{Data analysis}

ArcGis 10.2 was employed to draft the figures depicting the distribution of sampling points and the development of each index. Excel 2007 was adopted to organize the data that reveal the content of each index and calculate the average value, over-standard rate, and the coefficient of variation (C.V). Origin 9.6 was applied to create a dotted-line chart to demonstrate the distribution of each pollution index of the sampling points. SPSS 22.0 was used to conduct a Pearson correlation analysis on each index in the water sample. Subsequently, an analysis of the contamination sources was conducted on the basis of the level of correlation.

\subsection{Method for evaluating the quality of surface}

\section{water}

The Nemerow Pollution Index method is commonly applied for evaluating the water environment of basins. This method can calculate a single pollutant index as well as the comprehensive indexes of different factors within the basin and reflect the comprehensive contamination situation ${ }^{[7-8]}$. According to the environmental quality standards for surface water (GB3838-2002) III standard value ${ }^{[9]}$, the calculation formulas are as follows:

$$
I_{i}=\frac{C_{i}}{C O_{i}}
$$




$$
W Q I=\sqrt{\left(I_{i, \max }\right)^{2}+\left(\frac{1}{j \sum_{i=1}^{j} I_{i}}\right)^{2}} / 2
$$

In formula (1) and (2), $I_{i}$ and $I_{i, \max }$ refer to the contamination index and maximum contamination index of index $i$, respectively; $C_{i}$ indicates the mass concentration $(\mathrm{mg} / \mathrm{L})$ of index $i$; $C O_{i}$ represents the standard mass concentration $(\mathrm{mg} / \mathrm{L})$ of index $I$; WQI stands for the comprehensive water quality indexes; and $\mathrm{j}$ signifies the number of ions.

The degree of contamination caused by the indexes was classified into four levels to calculate a single contamination index: (1) $I_{i}<1$, clean (2) $1 \leq I_{i}<2$, moderately clean; (3) $2 \leq I_{i}<$ 3 , contaminated; (4) $3 \leq I_{i}$, severely contaminated.

According to the results of the calculated comprehensive contamination indexes, water quality was graded into five levels ${ }^{[10]}$ : (1) $W Q I<0.80$, excellent water quality; (2) $0.81 \leq$ $W Q I<2.50$, good water quality; (3) $2.51 \leq W Q I<4.25$, moderate water quality; (4) $4.25 \leq W Q I<7.20$, poor water quality; and (5) $W Q I \geq 7.20$, very poor water quality.

\section{Results and analysis}

\subsection{Analysis and assessments of the indexes in the}

\section{water sample}

\subsubsection{Analysis and assessments of the cations and}

\section{anions in the water sample}

Table 1 present the mass concentration of ions in the surface water at each sampling point within the Shandi River basin. The content of $\mathrm{Fe}^{3+}$ ranged from 0 to $1.276 \mathrm{mg} / \mathrm{L}$, the average value was $151.64 \mathrm{mg} / \mathrm{L}$, and the over-standard rate reached $64 \%$. $\mathrm{Fe}^{3+}$ was assessed at sampling points $\mathrm{S} 2-\mathrm{S} 11$; the content of $\mathrm{Fe}^{3+}$ at sampling points $\mathrm{S} 1$ and $\mathrm{S} 2$ was lower than the minimum detection limit of the equipment and is marked as 0 . This indicated that $\mathrm{Fe}^{3+}$ did not exceed the standard in the upstream area generally. The content of $\mathrm{Fe}^{3+}$ reached its peak at $\mathrm{S} 6$, where the content of $\mathrm{Fe}^{3+}$ severely exceeded the standard; also, $\mathrm{Fe}^{3+}$ showed the highest degree of variation, with a C.V of $278 \%$. The reason for this finding is that sampling point S6 is located near contamination source IV, where the acid mine drainage contamination is serious. The drainage contains abundant $\mathrm{Fe}^{3+}$, and when the outflow increases, the content of $\mathrm{Fe}^{3+}$ rises accordingly. Furthermore, $\mathrm{Fe}^{3+}$ accumulates easily, and $\mathrm{Fe}^{3+}$ content declines at a faster rate with the movement of flowing water; therefore, the spatial heterogeneity of $\mathrm{Fe}^{3+}$ was the most apparent ${ }^{[11-12]}$. The content of $\mathrm{Fe}^{2+}$ ranged from 0 to $1364 \mathrm{mg} / \mathrm{L}$, the average value was $590.86 \mathrm{mg} / \mathrm{L}$, and the over-standard rate was $55 \%$. $\mathrm{Fe}^{2+}$ was evaluated at sampling points $\mathrm{S} 6-\mathrm{S} 11$; the content of $\mathrm{Fe}^{2+}$ at $\mathrm{S} 6-\mathrm{S} 7$ and $\mathrm{S} 9$ was lower than the minimum detection limit of the equipment and is marked as 0 . This indicated that $\mathrm{Fe}^{2+}$ did not exceed the standard in the upstream and midstream in general. Nonetheless, the content of $\mathrm{Fe}^{2+}$ was extremely high at S6-S7 and S9, and the reason is that S6 is located near contamination source IV and S9 adjoins contamination source V. In addition to $\mathrm{Fe}^{3+}, \mathrm{Fe}^{2+}$ is also abundant in acid mine drainage, and when the outflow increases, the content of $\mathrm{Fe}^{2+}$ rises accordingly; in addition, $\mathrm{Fe}^{2+}$ does not accumulate easily, so its content sampled at $\mathrm{S} 7$ remained high ${ }^{[13]}$. The content of $\mathrm{SO}_{4}{ }^{2-}$ ranged from 71.40 to $19836 \mathrm{mg} / \mathrm{L}$, the average value was $5883.09 \mathrm{mg} / \mathrm{L}$, and the over-standard rate came to $81 \%$. $\mathrm{SO}_{4}{ }^{2-}$ was assessed at sampling points $\mathrm{S} 1-\mathrm{S} 11$; the content of $\mathrm{SO}_{4}{ }^{2-}$ at $\mathrm{S} 6, \mathrm{~S} 7$, and $\mathrm{S} 9$ was extremely high, which proved that the $\mathrm{SO}_{4}{ }^{2-}$ content exceeded the standard at $\mathrm{S} 6, \mathrm{~S} 7$, and sampling points $\mathrm{S}$. The reason is that plentiful $\mathrm{SO}_{4}{ }^{2-}$ can be found in acid mine drainage, and with the abrupt increase of the outflow, the content of $\mathrm{SO}_{4}{ }^{2-}$ became exceedingly high. The content of $\mathrm{NO}_{3}{ }^{-}$ranged from 0.33 to $28 \mathrm{mg} / \mathrm{L}$, the average value was $10.22 \mathrm{mg} / \mathrm{L}$, and the over-standard rate was $45 \%$. $\mathrm{NO}_{3}{ }^{-}$was assessed at sampling points $\mathrm{S} 1-\mathrm{S} 11$, and the $\mathrm{NO}_{3}{ }^{-}$ content reached its peak at S5. The reason is that S5 is located within the range of influence of contamination source II. The secondary sewage used by the pig farm is discharged into the river course, and water quality deteriorates with the release of the highly concentrated organic sewage, which leads to the increase and exceedance of $\mathrm{NO}_{3}{ }^{-}{ }^{[14]}$. The content of $\mathrm{Cl}^{-}$ ranged from 13 to $158 \mathrm{mg} / \mathrm{L}$, the average value was 76.59 $\mathrm{mg} / \mathrm{L}$, and the over-standard rate was $0 \%$, which indicated that the $\mathrm{Cl}^{-}$content of the Shandi River basin met the grade III water quality standards in China. The content of $\mathrm{F}^{-}$ranged from 0.43 to $15 \mathrm{mg} / \mathrm{L}$, the average value was $4.17 \mathrm{mg} / \mathrm{L}$, and the over-standard rate was $45 \% . \mathrm{F}^{-}$was inspected at sampling points $\mathrm{S} 1-11$; the content of $\mathrm{F}^{-}$was excessively high at $\mathrm{S} 6, \mathrm{~S} 7$, and S9 and exceeded the standard because the three sampling points are near acid mine drainage contamination sources IV and V. However, acid mine drainage cannot be asserted to be the cause of the exceedance of $\mathrm{F}^{-}$because it is not a feature of acid mine drainage. Accordingly, Pearson correlation analysis was employed to analyze the $\mathrm{F}^{-}$identified in the Shandi River and the features $\mathrm{Fe}^{3+}, \mathrm{Fe}^{2+}$, and $\mathrm{SO}_{4}^{2-}$ in acid mine drainage, 
and the results revealed that $\mathrm{F}^{-}$has a positive correlation $(p<$ 0.01) with $\mathrm{Fe}^{3+}, \mathrm{Fe}^{2+}$, and $\mathrm{SO}_{4}{ }^{2-}$, and the correlation coefficients were $0.75,0.85$, and 0.98 , respectively. This indicated that $\mathrm{F}^{-}$has a similar source as $\mathrm{Fe}^{3+}, \mathrm{Fe}^{2+}$, and $\mathrm{SO}_{4}{ }^{2-}$ and could further imply that contamination sources IV and Vcaused the exceedance of $\mathrm{F}^{-}$at $\mathrm{S} 6, \mathrm{~S} 7$, and $\mathrm{S} 9$.

Table 1. Mass concentration and the distributions of ions in the surface water collected at the sampling points in the Shandi River basin

\begin{tabular}{cccccccc}
\hline Items & $\mathrm{Fe}^{3+}$ & $\mathrm{Fe}^{2+}$ & $\mathrm{SO}_{4}^{2-}$ & $\mathrm{NO}^{3-}$ & $\mathrm{NO}^{2-}$ & $\mathrm{Cl}^{-}$ & $\mathrm{F}^{-}$ \\
\hline Minimum value/mg $\cdot \mathrm{L}^{-1}$ & 0 & 0 & 71.40 & 0.33 & 0.02 & 13 & 0.43 \\
Maximum value/mg $\mathrm{L}^{-1}$ & 1276 & 1364 & 19836 & 28. & 34.6 & 158 & 15 \\
Average value/mg $\cdot \mathrm{L}^{-1}$ & 151.64 & 590.86 & 5883.09 & 10.22 & 5.63 & 76.59 & 4.17 \\
Standard value/mg. $\mathrm{L}^{-1}$ & 0.30 & 0.30 & 250 & 10 & 10 & 250 & 1 \\
Over-standard rate/\% & 64 & 55 & 81 & 45 & 9 & 0 & 45 \\
C.V & 2.78 & 1.05 & 1.32 & 0.94 & 2.20 & 0.64 & 1.35 \\
\hline
\end{tabular}

\subsubsection{Analysis and Evaluation of the heavy metal factors in the water}

Table 2 display the heavy metal concentration at the sampling points within the Shandi River basin. Pearson correlation analysis was employed to analyze the correlation between the heavy metals and the cations and anions in the basin to explore their possible source. The content of $\mathrm{Zn}$ ranged from 0.0128 to $22.4 \mathrm{mg} / \mathrm{L}$, the average value was $5.58 \mathrm{mg} / \mathrm{L}$, and the over-standard rate was $36 \%$. The content of $\mathrm{Zn}$ inspected at sampling pointsS1-S11 was highest at S6 and S7. Zn had a significant correlation with the acid mine water features $\mathrm{Fe}_{3}{ }^{+}$, $\mathrm{Fe}_{2}{ }^{+}, \mathrm{SO}_{4}{ }^{2-}$, and $\mathrm{F}^{-}$, which indicated that the contamination sources were similar and proved that acid mine drainage contamination source IV was the cause of the sudden increase of $\mathrm{Zn}$ at S6 and S7. The content of As ranged from 0.0001 to $0.05 \mathrm{mg} / \mathrm{L}$, the average value was $0.0003 \mathrm{mg} / \mathrm{L}$, and the overstandard rate was $0 \%$. This demonstrated that the As content met the grade III water quality standards in China. The content of $\mathrm{Hg}$ ranged from 0.0002 to $0.0006 \mathrm{mg} / \mathrm{L}$, the average value was $0.0004 \mathrm{mg} / \mathrm{L}$, and the over-standard rate reached $40 \%$. The content of $\mathrm{Hg}$ inspected at $\mathrm{S} 1-\mathrm{S} 3$ and in the S1 water sample was lower than the minimum detection limit of the equipment and is marked as 0 . This indicated that $\mathrm{Hg}$ did not contaminate the river at sampling points $\mathrm{S} 1-\mathrm{S} 3$ and $\mathrm{S} 1$, but the content of $\mathrm{Hg}^{-}$was relatively high at $\mathrm{S} 5, \mathrm{~S} 6$, and $\mathrm{S} 9 . \mathrm{Hg}$ had a significant correlation and shared a similar source with the acid mine drainage feature $\mathrm{Fe}^{2+}$, which confirmed that the higher content of $\mathrm{Hg}$ at S5 was caused by acid mine drainage contamination source II, and S6-S7 were influenced by contamination sources IV and V. The content of $\mathrm{Cd}$ ranged from 0.0004 to $0.566 \mathrm{mg} / \mathrm{L}$, the average value was $0.1283 \mathrm{mg} / \mathrm{L}$, and the over-standard rate reached 55\%. Sites S6, S7, and S9 were inspected and found to have a higher content of Cd than sampling points $\mathrm{S} 1-11$.

Table. 2 Mass concentration and distributions of the heavy metals in the surface water collected at each sampling point in the Shandi River basin

\begin{tabular}{cccccccc}
\hline Items & $\mathrm{Zn}$ & $\mathrm{As}$ & $\mathrm{Hg}$ & $\mathrm{Cd}$ & $\mathrm{Cr}^{6+}$ & $\mathrm{Pb}$ & $\mathrm{Mn}$ \\
\hline Minimum value $/ \mathrm{mg} \cdot \mathrm{L}^{-1}$ & 0.0128 & 0.0001 & 0.0002 & 0.0004 & 0 & 0.0032 & 0.0105 \\
Maximum value $/ \mathrm{mg} \cdot \mathrm{L}^{-1}$ & 22.4 & 0.0005 & 0.0006 & 0.566 & 0 & 0.0092 & 91.2 \\
Average value $/ \mathrm{mg} \cdot \mathrm{L}^{-1}$ & 5.5837 & 0.0003 & 0.0004 & 0.1283 & 0 & 0.0046 & 23.5683 \\
Standard value $/ \mathrm{mg} \cdot \mathrm{L}^{-1}$ & 1 & 0.05 & 0.0001 & 0.005 & 0.05 & 0.05 & 0.1 \\
Over-standard value/\% & 36 & 0 & 55 & 55 & 0 & 0 & 81 \\
C.V & $165 \%$ & $63 \%$ & $40 \%$ & $164 \%$ & - & $45 \%$ & $150 \%$ \\
\hline
\end{tabular}

\subsubsection{Analysis and evaluation of the content of $\mathrm{CN}^{-}$,} volatile phenols, $\mathrm{H}_{2} \mathrm{~S}, \mathrm{NH}_{3}-\mathrm{N}$, and $\mathrm{COD}$ in the water sample

Table 3 display the mass concentration of $\mathrm{CN}^{-}$, volatile phenols, $\mathrm{H}_{2} \mathrm{~S}, \mathrm{NH}_{3}{ }^{-} \mathrm{N}$, and $\mathrm{COD}$ at the sampling points placed 
within the Shandi River basin. Pearson correlation analysis was employed to analyze the relationships between the cations and anions and the content of $\mathrm{CN}^{-}$, volatile phenols, $\mathrm{H}_{2} \mathrm{~S}, \mathrm{NH}_{3}{ }^{-} \mathrm{N}$, and COD separately to explore their possible sources, and the results are listed in Table 4. The content of $\mathrm{CN}^{-}$was lower than the minimum detection limit of the equipment at sampling points $\mathrm{S} 1-\mathrm{S} 11$, which indicated that the $\mathrm{CN}^{-}$content met the grade III water quality standards in China. The content of volatile phenols ranged from 0.002 to $0.005 \mathrm{mg} / \mathrm{L}$, the average value was $0.0033 \mathrm{mg} / \mathrm{L}$, and the over-standard rate was $0 \%$. This also indicated that the content of volatile phenols within the Shandi River basin metthe grade III water quality standards in China. The content of $\mathrm{H}_{2} \mathrm{~S}$ ranged from 0 to $0.35 \mathrm{mg} / \mathrm{L}$, the average value was $0.1045 \mathrm{mg} / \mathrm{L}$, and the over-standard rate was $18 \%$. The $\mathrm{H}_{2} \mathrm{~S}$ content inspected at S1, S2, S9, and S11 was relatively high. According to Table $4, \mathrm{H}_{2} \mathrm{~S}$ had no significant correlation with the acid mine drainage ions, proving that their contamination sources were different and the reason for the exceedance remains to be identified. The content of $\mathrm{NH}_{3}-\mathrm{N}$ ranged from
6.22 to $63.8 \mathrm{mg} / \mathrm{L}$, the average value was $22.0333 \mathrm{mg} / \mathrm{L}$, and the over-standard rate reached $81 \%$. The content of $\mathrm{NH}_{3}-\mathrm{N}$ inspected at S3, S6, S7, and S9 was relatively high. Based on Table $4, \mathrm{NH}_{3}-\mathrm{N}$ had a positive correlation with the acid mine drainage feature ions $\mathrm{Fe}^{2+}$ and $\mathrm{SO}_{4}{ }^{2-}$. This indicated that the contamination sources were similar and confirmed that mine washery contamination source I was the cause of the higher $\mathrm{NH}_{3}-\mathrm{N}$ content at $\mathrm{S} 3$, whereas acid mine drainage contamination sources IV and $\mathrm{V}$ were the reason for the higher $\mathrm{NH}_{3}-\mathrm{N}$ content at $\mathrm{S} 6, \mathrm{~S} 7$, and $\mathrm{S} 9$. The content of $\mathrm{NH}_{3}-$ $\mathrm{N}$ ranged from 6.22 to $63.8 \mathrm{mg} / \mathrm{L}$, the average value was $22.0333 \mathrm{mg} / \mathrm{L}$, and the over-standard rate reached $81 \%$. The content of COD ranged from 0.8 to $240 \mathrm{mg} / \mathrm{L}$, the average value was $49.3785 \mathrm{mg} / \mathrm{L}$, and the over-standard rate was $27 \%$. The concentration of COD inspected at S7 and S9 was relatively high. Based on Table 4, the COD concentration has no significant correlation with the acid mine drainage features; accordingly, the contamination sources were different, and the reason for the contamination remains to be known.

Table 3. Mass concentration and the distributions of the factors collected at the sampling points in the Shandi River basin

\begin{tabular}{cccccc}
\hline Items & $\mathrm{CN}^{-}$ & Volatile phenols & $\mathrm{H}_{2} \mathrm{~S}$ & $\mathrm{NH}_{3}-\mathrm{N}$ & $\mathrm{COD}$ \\
\hline Minimum value $/ \mathrm{mg} \cdot \mathrm{L}^{-1}$ & 0 & 0.002 & 0 & 6.22 & 0.8 \\
Maximum value $/ \mathrm{mg} \cdot \mathrm{L}^{-1}$ & 0 & 0.005 & 0.35 & 63.8 & 240 \\
Average value $/ \mathrm{mg} \cdot \mathrm{L}^{-1}$ & 0 & 0.0033 & 0.1045 & 22.0333 & 49.3785 \\
Standard value $/ \mathrm{mg} \cdot \mathrm{L}^{-1}$ & 0.02 & 0.005 & 0.2 & 1 & 20 \\
Over-standard value/\% & 0 & 0 & 18 & 81 & 27 \\
C.V & - & $45 \%$ & $126 \%$ & $89 \%$ & $173 \%$ \\
\hline
\end{tabular}

Table 4. Correlation analysis between the factors $\mathrm{CN}^{-}$, volatile phenols, $\mathrm{H}_{2} \mathrm{~S}, \mathrm{NH}_{3}{ }^{-} \mathrm{N}$, and $\mathrm{COD}$ and ions

\begin{tabular}{|c|c|c|c|c|c|c|c|c|c|c|c|c|}
\hline & $\mathrm{CN}^{-}$ & Phenol & $\mathrm{H}_{2} \mathrm{~S}$ & $\mathrm{NH}_{3}-\mathrm{N}$ & COD & $\mathrm{Fe}^{3+}$ & $\mathrm{Fe}^{2+}$ & $\mathrm{SO}_{4}{ }^{2-}$ & $\mathrm{NO}_{3}^{-}$ & $\mathrm{NO}_{2}^{-}$ & $\mathrm{Cl}^{-}$ & $\mathrm{F}$ \\
\hline $\mathrm{CN}^{-}$ & 1 & & & & & & & & & & & \\
\hline Phenol & - & 1 & & & & & & & & & & \\
\hline $\mathrm{H}_{2} \mathrm{~S}$ & - & -0.391 & 1 & & & & & & & & & \\
\hline $\mathrm{NH}_{3}-\mathrm{N}$ & - & -0.11 & -0.108 & 1 & & & & & & & & \\
\hline COD & - & -0.124 & 0.530 & 0.358 & 1 & & & & & & & \\
\hline $\mathrm{Fe}^{3+}$ & - & -0.244 & -0.129 & $-0.788^{* *}$ & -0.111 & 1 & & & & & & \\
\hline $\mathrm{Fe}^{2+}$ & - & -0.249 & 0.156 & $0.852 * *$ & 0.599 & $0.673^{* *}$ & 1 & & & & & \\
\hline $\mathrm{SO}_{4}{ }^{2-}$ & - & -0.169 & -0.123 & $0.813 * *$ & 0.356 & $0.694 *$ & $0.928 * *$ & 1 & & & & \\
\hline $\mathrm{NO}_{3}{ }^{-}$ & - & -0.103 & -0.367 & -0.474 & -0.462 & -0.339 & $-0.645^{*}$ & $-0.608 *$ & 1 & & & \\
\hline $\mathrm{NO}_{2}^{-}$ & - & 0.582 & -0.266 & 0.230 & -0.061 & -0.119 & -0.217 & -0.220 & 0.188 & 1 & & \\
\hline
\end{tabular}




\begin{tabular}{lllllllllllll}
$\mathrm{Cl}^{-}$ & - & -0.248 & -0.595 & 0.553 & -0.142 & $0.611^{*}$ & 0.412 & 0.521 & 0.198 & -0.070 & 1 & \\
$\mathrm{~F}^{-}$ & - & -0.154 & -0.187 & $-0.840^{* *}$ & 0.251 & $0.750^{* *}$ & $0.892 * *$ & $0.981 * *$ & -0.534 & -0.120 & 0.559 & 1 \\
\hline
\end{tabular}

\subsubsection{Summary}

Based on the preceding analysis results, the content of $\mathrm{Cl}^{-}$, As, $\mathrm{Cr}^{6+}, \mathrm{Pb}, \mathrm{CN}^{-}$, and volatile phenols met the grade III water quality standards in China, whereas the remaining indexes exceeded the standards by varying degrees. The concentrations of $\mathrm{NO}_{2}{ }^{-}$and $\mathrm{NH}_{3}-\mathrm{N}$ were higher near contamination source I; stated differently, contamination source I had a greater influence on the content of $\mathrm{NO}_{2}{ }^{-}$and $\mathrm{NH}_{3}-\mathrm{N}$. The concentrations of $\mathrm{NO}_{3}{ }^{-}$and $\mathrm{Hg}$ significantly increased near contamination source II; specifically, contamination source II had a greater influence on the content of $\mathrm{NO}_{3}{ }^{-}$and $\mathrm{Hg}$ in the river. The concentration of $\mathrm{NO}_{3}{ }^{-}$and $\mathrm{Hg}$ somewhat intensified near contamination source III, which would suggest that contamination source III had a greater influence on the content of $\mathrm{NO}_{3}{ }^{-}$and $\mathrm{Hg}$ in the river. The concentrations of $\mathrm{Fe}^{3+}, \mathrm{Fe}^{2+}, \mathrm{SO}_{4}{ }^{2-}, \mathrm{F}^{-}, \mathrm{Zn}, \mathrm{Hg}$, $\mathrm{Cd}$, and $\mathrm{Mn}$ were significantly elevated near contamination source IV; therefore, contamination source IV most strongly influenced the content of $\mathrm{Fe}^{3+}, \mathrm{Fe}^{2+}, \mathrm{SO}_{4}{ }^{2-}, \mathrm{F}^{-}, \mathrm{Zn}, \mathrm{Hg}, \mathrm{Cd}$, and $\mathrm{Mn}$ in the river. The concentrations of $\mathrm{Fe}^{2+}, \mathrm{SO}_{4}{ }^{2-}, \mathrm{F}^{-}$, $\mathrm{Hg}, \mathrm{Cd}$, and $\mathrm{Mn}$ were significantly higher at sampling sites near contamination source $\mathrm{V}$; accordingly, contamination source $\mathrm{V}$ can be said to have most strongly affected the content of $\mathrm{Fe}^{2+}, \mathrm{SO}_{4}{ }^{2-}, \mathrm{F}^{-}, \mathrm{Hg}, \mathrm{Cd}$, and $\mathrm{Mn}$ in the river. According to the results, the five contamination sources all negatively affected the environment of the basin, particularly acid mine drainage contamination sources IV and V. The mass concentration of most indexes fluctuated within a wide range, but the patterns of the fluctuation were identical: values increased abruptly near the contamination source but generally decreased in the order of downstream $>$ midstream $>$ upstream.

\subsection{Water quality evaluation analysis and results}

\subsubsection{Analysis and results of each single contamination index}

The evaluation of the influence level of each single contamination index was calculated using single contamination indexes. The results demonstrated that the river was not contaminated by $\mathrm{Cl}^{-}, \mathrm{As}, \mathrm{Cr}^{6+}, \mathrm{Pb}, \mathrm{CN}^{-}$, volatile phenols, or $\mathrm{H}_{2} \mathrm{~S}$, but it was contaminated by $\mathrm{Fe}^{3+}, \mathrm{Fe}^{2+}, \mathrm{SO}_{4}{ }^{2-}$, $\mathrm{NO}_{3}{ }^{-}, \mathrm{NO}_{2}{ }^{-}, \mathrm{F}^{-}, \mathrm{Zn}, \mathrm{Hg}, \mathrm{Mn}, \mathrm{Cd}, \mathrm{NH}_{3}{ }^{-} \mathrm{N}$, and $\mathrm{COD}$ by varying degrees. The severity of each single contamination index descends in the following listed order: $\mathrm{Fe}^{2+}>\mathrm{Fe}^{3+}>\mathrm{Mn}>$ $\mathrm{SO}_{4}{ }^{2}>\mathrm{Cd}>\mathrm{NH}_{3}-\mathrm{N}>\mathrm{Zn}>\mathrm{F}^{-}>\mathrm{Hg}>\mathrm{COD}>\mathrm{NO}_{3}{ }^{-}>\mathrm{NO}_{2}{ }^{-}$. The proportion of each contamination index at the sampling points is in the order of $\mathrm{SO}_{4}{ }^{2-}=\mathrm{Mn}=\mathrm{NH}_{3}-\mathrm{N}>\mathrm{Fe}^{2+}=\mathrm{Hg}>\mathrm{Fe}^{3+}>\mathrm{Cd}$ $>\mathrm{Zn}=\mathrm{F}^{-}>\mathrm{COD}>\mathrm{NO}_{3}{ }^{-}=\mathrm{NO}_{2}{ }^{-}$. This indicated that the content of $\mathrm{Fe}^{2+}$ caused the highest level of contamination, and the content of $\mathrm{SO}_{4}{ }^{2-}, \mathrm{Mn}$, and $\mathrm{NH}_{3}-\mathrm{N}$ had the widest contamination range. The distribution of each contamination index is displayed in Figure 3. $\mathrm{Fe}^{3+}, \mathrm{Fe}^{2+}, \mathrm{SO}_{4}{ }^{2-}, \mathrm{F}^{-}, \mathrm{Zn}, \mathrm{Hg}$, $\mathrm{Mn}, \mathrm{Cd}$, and $\mathrm{NH}_{3}{ }^{-} \mathrm{N}$ had relatively high contamination indexes near sampling point S6. The contamination source analysis showed that S6 was influenced by contamination source IV, which resulted in the high contamination indexes of the factors listed above. The content of $\mathrm{Fe}^{2+}, \mathrm{SO}_{4}{ }^{2-}, \mathrm{F}^{-}, \mathrm{Zn}$, $\mathrm{Hg}, \mathrm{Mn}, \mathrm{Cd}, \mathrm{NH}_{3}-\mathrm{N}$, and COD also exhibited increases. The contamination source analysis revealed that $S 9$ was affected by contamination source $\mathrm{V}$, which resulted in high contamination indexes in the factors $\mathrm{Fe}^{2+}, \mathrm{SO}_{4}{ }^{2-}, \mathrm{F}^{-}, \mathrm{Zn}, \mathrm{Hg}$, $\mathrm{Mn}, \mathrm{Cd}$, and $\mathrm{NH}_{3}-\mathrm{N}$, whereas the contamination source of COD remains to be clarified. The outflow of acid mine drainage led to a critical level of contamination at S6 and S9. 

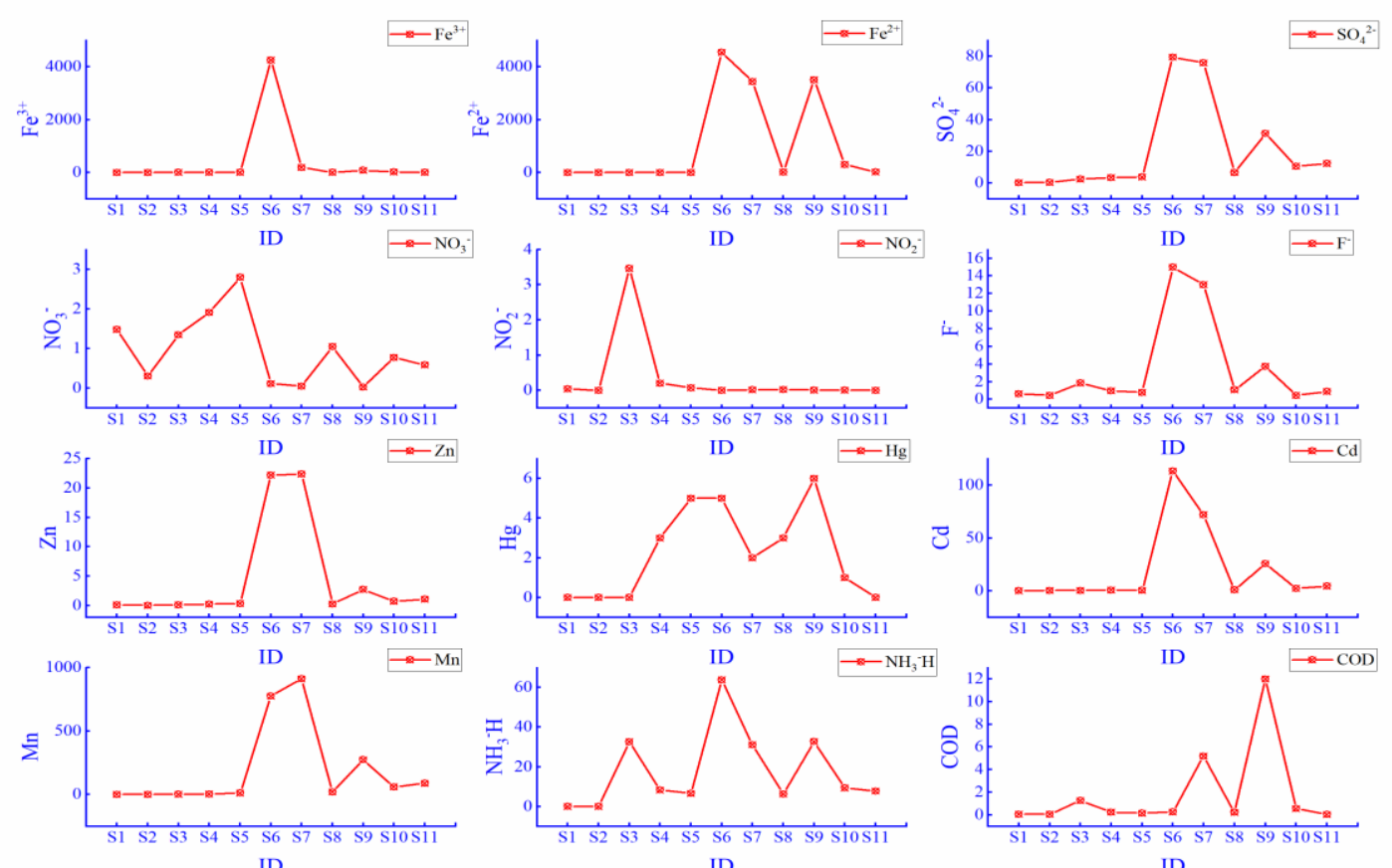

ID

Figure 3. Distribution of the contamination indexes

\subsubsection{Results and analysis of the comprehensive}

\section{contamination indexes}

The evaluation results concerning Shandi River water quality comprehensive contamination indexes were obtained through the calculation of the heavy metal comprehensive indexes at the sampling points (see Table 5). The results revealed that only the water quality at S1 and S2 was graded excellent, whereas that at the other nine sampling points was very poor. The severity of the comprehensive contamination indexes decreased in the order of $\mathrm{S} 6>\mathrm{S} 9>\mathrm{S} 7>\mathrm{S} 11>\mathrm{S} 10>\mathrm{S} 3>$ $\mathrm{S} 8>\mathrm{S} 5>\mathrm{S} 4$. Areas with severe and long-term contamination surrounded the Shandi River village, and the two areas with acid mine drainage contamination were in the most impaired condition.

Table 5. Result of the evaluation of Shandi River water

\begin{tabular}{ccc}
\multicolumn{3}{c}{ quality } \\
\hline & & Grading results of \\
ID & WQI & the water quality \\
\hline S1 & 0.74 & Excellent \\
S2 & 0.42 & Excellent \\
S3 & 265.69 & Very poor \\
S4 & 16.97 & Very poor \\
\hline
\end{tabular}

\begin{tabular}{ccc}
\hline S5 & 39.69 & Very poor \\
S6 & 5168044.44 & Very poor \\
S7 & 2958400.00 & Very poor \\
S8 & 98.01 & Very poor \\
S9 & 3062500.00 & Very poor \\
S10 & 22151.36 & Very poor \\
S11 & 1951166.92 & Very poor \\
\hline
\end{tabular}

\section{Conclusion and suggestions}

This study conducted field surveys and discovered the distribution of the contamination sources in the Shandi River basin; based on the results of the surveys, sampling points were placed at the contamination sources to obtain water sample data for water quality evaluation. The results are as follows:

(1)The content of $\mathrm{Cl}^{-}, \mathrm{As}, \mathrm{Cr}^{6+}, \mathrm{CN}^{-}$, and volatile phenols met the grade III water quality standards, whereas the remaining indexes all exceeded the standards by varying degrees. Five contamination sources were found within the basin, and each source had a negative influence on the water quality in the basin. Contamination source I had a major influence on the content of $\mathrm{NO}_{2}^{-}$and $\mathrm{NH}_{3}-\mathrm{H}$ in the river; contamination source II caused the high content of $\mathrm{NO}_{3}{ }^{-}$and $\mathrm{Hg}$; contamination source III affected the content of $\mathrm{NO}_{3}{ }^{-}$and $\mathrm{Hg}$; contamination source VI increased the content of $\mathrm{Fe}^{3+}$, 
$\mathrm{Fe}^{2+}, \mathrm{SO}_{4}{ }^{2-}, \mathrm{F}^{-}, \mathrm{Zn}, \mathrm{Hg}$, and $\mathrm{Mn}$; and contamination source $\mathrm{V}$ was the cause of elevated levels of $\mathrm{Fe}^{2+}, \mathrm{SO}_{4}{ }^{2-}, \mathrm{F}^{-}, \mathrm{Hg}$, and $\mathrm{Mn}$ in the river. The patterns of the variations in mass concentration were identical in terms of most factors: values increased abruptly near the contamination sources and generally decreased in the order of downstream $>$ midstream $>$ upstream.

(2)The river was not contaminated by the content of $\mathrm{Cl}^{-}, \mathrm{As}, \mathrm{Cr}^{6+}, \mathrm{Pb}, \mathrm{CN}^{-}$, volatile phenols, or $\mathrm{H}_{2} \mathrm{~S}$ but was contaminated by $\mathrm{Fe}^{3+}, \mathrm{Fe}^{2+}, \mathrm{SO}_{4}{ }^{2-}, \mathrm{NO}_{3}{ }^{-}, \mathrm{NO}_{2}{ }^{-}, \mathrm{F}^{-}, \mathrm{Zn}, \mathrm{Hg}, \mathrm{Mn}, \mathrm{Cd}$, $\mathrm{NH}_{3}{ }^{-} \mathrm{N}$, and $\mathrm{COD}$ by varying degrees. The level of contamination by each index decreased in the order of $\mathrm{Fe}^{2+}>\mathrm{Fe}^{3+}>\mathrm{Mn}>\mathrm{SO}_{4}{ }^{2}>\mathrm{Cd}>\mathrm{NH}_{3}-\mathrm{N}>\mathrm{Zn}>\mathrm{F}>\mathrm{Hg}>\mathrm{COD}>\mathrm{NO}_{3}{ }^{-}$ $>\mathrm{NO}_{2}{ }^{-} . \mathrm{Fe}^{2+}$ was responsible for the highest level of contamination within the Shandi River basin, and $\mathrm{SO}_{4}{ }^{2-}, \mathrm{Mn}$, and $\mathrm{NH}_{3}-\mathrm{H}$ exhibited the widest range of contamination.

(3)Within the Shandi River basin, only the water quality at S1 and S2 was graded excellent, whereas that at the remaining sampling points was very poor. The severity of the comprehensive contamination indexes decreased in the order of $\mathrm{S} 6>\mathrm{S} 9>\mathrm{S} 7>\mathrm{S} 11>\mathrm{S} 10>\mathrm{S} 3>\mathrm{S} 8>\mathrm{S} 5>\mathrm{S} 4$. Areas with serious and long-term contamination exist around the Shandi River village, and the two areas with acid mine drainage contamination were in the most severe condition.

Given the contamination within the Shandi River basin, upstream regulations are suggested to lower the harm to the Niangzi Pass spring field. Abandoned open-pit mines should be filled, and the garbage in the mines should be disposed of properly. The mine shafts should be sealed to prevent the oxidization of mine water. Additionally, on-site processing measures are recommended (e.g., permeable reactive barriers(PRB) or phytoremediation techniques) to deal with the contamination that has already been caused by acid mine drainage.

\section{References}

1. Q. Liu ,Y. B. Zhang, Z. X. Zhang, et al. Study on the Formation Mechanism and Disposal Technology of Acidic Old Air Water in Coal Mines[J]. Coal Tech,36(10):163-165 (2017).

2. Y. P. Liang, C. H. Zhao, C. L. Tang, et al. Reanalysis of the Causes of Guanquan Water and Pollution in Shanxi Niangzi[J]. Chin Karst, 36(05):633-640 (2017) .
3. J. G. Huo . Analysis on Causes and Pathways of Karst Water Pollution in Niangziguan Spring Area of Yangquan City[J]. Shanxi Water Res Sci Tech,(01):67-70+79 (2015). 4. T. L .Wang . Analysis of the Influence of Coal Mining on the Quality of Karst Groundwater in Niangziguan Spring Basin[J]. Groundwater,37(06):34-35 (2015).

5. Y. Liu, Y. J. Sun, M. Wang . Water quality characteristics and emission pollution of mine water $[\mathrm{J}]$. Clean Coal Tech,(03):83-86(2007).

6. J. Huang, L. M. Gao, S. P. Li . Analysis of Water Pollution Sources in Coal Mining Subsidence Area[J]. Environ Monitor Chin,29(06):66-69(2013).

7. W. Z. Tang , L. H. Wang , B. Q. Shan . Heavy metal pollution of the surface sediments in Daqing River System, Haihe Basin[J]. Acta Scientiae Circumstantiae,35(11): 3620(2015).

8. J. Q. Zhang, Q. Tian , D. M. Xu, et al. Pollution Characteristics and Risk Assessment of Heavy Metals in Water and Sediment from Daye Lake[J]. Environ Sci, 38(6): 2355-2366(2017).

9. B3838-2002, Groundwater Quality Standard[S]. Beijing: China Environmental Science Press(2002).

10. Y. C. Liu , Z. F. Liu , J .Liu ,et al. Distribution characteristics and risk assessment of ammonia nitrogen and heavy metal pollution in Longjing river, the upstream of Ganjiang river[J]. Nonferrous Metals Sci Eng, 10(4): 8593(2019).

11. P. F. Sun , Q .T. Yi , G. Q. Xu . Hydrochemical characteristics and influencing factors of water in the submerged area of Lianghuai coal mining area[J]. J Chin Coal Soc,39(07):1345-1353(2014).

12. F. H. Zhao,Z. Y. Cong,H. F. Sun,D. Y. Ren. The geochemistry of rare earth elements (REE) in acid mine drainage from the Sitai coal mine, Shanxi Province, North China[J]. Int J Coal Geol,70(1):235-297（2006）

13. M. Yue ,F. H. Zhao ,D. J. Ren . Study on the Chemical Characteristics of Acidic Water and Its Environmental Geochemical Information in Coal Mines[J]. Coal Geol Explor,(03):46-49 (2004).

14. Y. Wang, B. Liang, X. H. Zhang, et al. Study on the Migration Law of Acid Mine Water in Soil-Water Environment[J]. J Geolog Hazards Environ Protec,(01):36-41 (2008). 